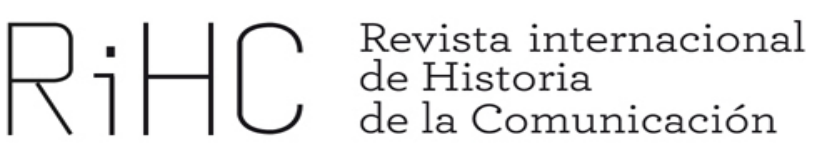

\title{
STRUCTURAL AND IDEOLOGICAL CHANGES IN THE OFFICIAL PRESS DURING THE SPANISH TRANSITION (1975-1978) ${ }^{1}$
}

DOI: http://dx.doi.org/10.12795/RiHC.2015.i04.07

Jezabel Martínez Fábregas

Universidad de Sevilla

jmartinez10@us.es

Recibido: 15-1-2015

Aceptado: 25-5-2015

Abstract: The Spanish Transition was a political process through which Spain reached the democratic status (1975- 1978). The yet authoritarian Spanish Government, in charge of the political change, dissolved the National Movement in April 1977 via the Law 1/1977 of $1^{\text {st }}$ of April. This initiative also entailed the end of the official press as such. Henceforth, it was included into the State Owned Social Media, and the evolution that led it abandoning its propaganda function started. These are the premises for this research that, by analysing technically and biographically seven official newspapers, shows that the official press evolved structurally and ideologically during the Spanish Transition.

\footnotetext{
${ }^{1}$ This paper presents part of the findings of the research project "El papel de la prensa diaria durante la transición a la democracia en España. Cobertura informativa y comportamiento politico de periódicos y periodistas". Project reference CSO 2012-36774, funded by R\&D Spanish National Plan 2012-2015, conducted by professor Jaume Guillamet i Lloveras (Universitat Pompeu Fabra, Barcelona, Spain).
} 
Keywords: Political and institutional Communication; Communication History in Spain; Spanish Transition; Francoist press; Spanish official press

Resumen: La Transición Española fue un proceso político a través del cual España alcanzó el estado democrático (1975-1978). El gobierno español aún autoritario, a cargo del cambio de régimen, disolvió el Movimiento Nacional en abril de 1977 a través de la ley 1/1977 de 1 de abril. Esta medida también conllevaba el fin de la prensa oficial como tal. Desde entonces, ésta fue incluida en los Medios de Comunicación Social del Estado (MCSE), y la evolución que los llevó a abandonar su función propagandística comenzó. Estas son las premisas de las que parte este estudio que, a través del análisis técnico y biográfico aplicado a siete diarios oficiales, demuestra que la prensa oficial evolucionó estructural e ideológicamente durante la Transición Española.

Palabras clave: Comunicación política e institucional; Historia de la Comunicación en España; Transición Española; prensa franquista; prensa oficial española

\section{Introduction}

The Spanish Transition is the political process through which Spain stopped being a dictatorship and became a democratic state. This is how Guillamet (2002) and Soto (1994) interpret this historical period. Such a political change process came also along with adjustments at legislative, economic, social, political, and journalistic levels (Barrera, 1995). Nevertheless, what do we consider as 'Spanish Transition' in terms of time?

This question has never been exempt from a deep controversy. Whereas most of the historians agree that Franco's death is the start point of the transition, they have never reached a consensus about its ending. Accordingly, Guillamet (2002) stresses that the political change finished with the referendum on the Constitution, whereas Mauri (2010) considers that the transition concluded when PSOE won the general elections in 1982, and Tussel (1995) asserts that the political change was done when Spain came into the European Economic Commission (CEE) in 1986.

Bearing this intense debate in mind, and considering that both seven years (1975-1982) as well as eleven years (1975-1986) are very extensive studying periods, we have followed the literal meaning of the word 'transition' ("the evolution from one state form to another", according to the Spanish Royal Academy) to select our studying period. Accordingly, the Spanish Transition has been interpreted in this study as the time lapse during which Spain moved from dictatorship to democracy. And, this is, according to Soto (1994: 110-111) and Guillamet (2002), from Franco's death $\left(20^{\text {th }}\right.$ of November 1975 ) to the referendum on the Constitution ( $6^{\text {th }}$ of December 1978), moment in which the democratic bases were set.

However, since we are dealing with official press during the Spanish Transition, we must highlight the fact that the adjustment in what concerns to the press took longer than 
the selected period. As the reprisals against journalists in Spain occurred until 1982, we must highlight that the informative transtion took, at least, from 1966 (when the law for press -law 14/1966 of $18^{\text {th }}$ of March- was passed by the Francoist Courts) to the general elections held in 1982 (Meneses, 2008). Considering these statements, and bearing in mind that we are analysing official newspapers during the transition, we could have posed a different studying period. Nevertheless, as this study aims at explaining how the political change, understood as Guillamet (2002) and Soto (1994) define it in terms of time (1975-1978), affected the official press, we will focus on the process through which Spain gained officially the status of democracy. This is, from November 1975 to December 1978.

Thus, to carry out this research we have analysed seven official newspapers edited in Spain during our studying period, consisting of 38 months. At this stage, nevertheless, what do we consider as official press in this study?

By using this term we refer to the dailies ascribed to the chain of the Movement's press, on the one hand, and to the Vertical Trade Union, on the other. From the 35 existing official dailies at the time (Zalbidea, 1996), we have analysed six from the chain of the movement's press, subsequently (from the $22^{\text {nd }}$ of April 1977 onwards) ascribed to the MCSE (Arriba, Solidaridad Nacional, El Pueblo Gallego, Hierro, Sur and Odiel), and Pueblo, owned by the Vertical Trade Union, a Francoist institution in charge of the dissemination of Francoism's propaganda during the dictatorship (Sánchez Glicerio, 2002).

These tabloids had been engendered as propaganda tools at Francoism's disposal (Alférez, 1986). Thus, during the dictatorship, the in-chain newspapers were to follow the dictates coming from the national-reference newspaper, Arriba, which, in turn, followed those that came from the National Movement, until its dissolution in April 1977. Also Pueblo, owned by the Vertical Trade Union, had to follow these dictates, at least, until the Vertical Trade Union was dissolved in 1976 (Gallegos, 2003). Subsequently, in June 1978, Pueblo was added into the MCSE.

Thus, once both institutions, the Vertical Trade Union and the National Movement, had disappeared in 1976 and 1977, respectively (Montabes Pereira, 1989), the official press was included into the MCSE. In spite of going on being state-owned press, turht is that it was left to its fate in a country in which there was a publications boom, such as El País, Diario 16, Cambio 16, etc. So, make it or break it, the official press needed to evolve urgently, adapting itself to the new readers' expectations.

Concerning the former, on the one hand, most of the authors have traditionally affirmed that the official press kept on being in communion with the Francoist ideology during the Spanish Transition, thus not undergoing any evolution process. In this connection, Montabes Pereira (1989) asserts that the official press went on comlying with the propaganda function that it had been entrusted during the dictatorship. Likewise, Alferez (1986) asseverates that, as official press, it went on disseminating the Francoist ideology, thus not allowing the entry of any other ideology, at least during Arias' turn in the Spanish Executive (Redero and García, 1991). 
Contrariwise, Castro Torres (2010) stressed that the official press tried to adapt to the political and the ideological pluralism existing in the country during the transition. Meneses (2008) went even further, by wondering whether different ideologies existing in Spain could have come into the official press' newsrooms. Martínez Fábregas (2014), on her part, concluded in 2014 that the official press abandoned its propaganda function during the Transition. Therefore, there was an evolution itself.

Anyway, whether the official press evolved trying to adapt itself to the new political landscape, this attempt was not fruitfull, as between 1979 and 1984, it closed down not having found any purchaser in public auction. This was the direct consequence of the real decrees $1434 / 79$, of $16^{\text {th }}$ of June 1979 and $60 / 84$, of $11^{\text {th }}$ of January 1984 .

At this point and resulting from this controversial debate about the structural, ideological and journalistic evolution of the official press during the political change process, our research question arises:

RQ: How did the official press evolve structurally, ideologically and journalistically during the Spanish Transition?

Once our research question posed, we proceed now to present the hypotheses assumed as start point for this research, and the goals we aim to achieve.

\section{Hypotheses and goals}

This study mainly aims at explaining the process through which the official press tried to adapt itself to the new political landscape during the Spanish Transition (1975-1978). It also intends to achieve the following goals:

> Analyse, at structural, ideological and journalistic levels, the evolution process through which the official press tried to adapt itself to the new political regime.

Evaluate the extent to which that evolution contributed to its adaptation to the new political landscape.

To reach these objectives, this study assumes as start point that the official press faced structural, ideological, and journalistic updates as part of its adaptation process to the new political and ideological landscape during the Spanish Transition. Apart from this main assumption, these are the hypotheses from which we start in this research:

(H1): Once the Francoism was over and the official press had lost the financial and the political support that the regime's institutions had provided it during the past 35 years, it had to reinvent itself structurally and 
journalistically for adjusting to the new political landscape, thus trying to set itself up as a political agent.

(H2): That reinvention, being the reaction to a political process in which different ideologies were involved, brought about modifications in the editorial board and the newsrooms, both of which welcomed different ideologies during the transition, thus reflecting the ideologically-plural landscape existing in Spain at the moment.

To achieve our goals, thus validating or refuting our hypotheses, we have used the following method.

\section{Method}

In this research, we have biographically analysed the official press during the selected studying period. On the one hand, we have studied six of the 34 newspapers from the chain of the Movement's press (Arriba, Solidaridad Nacional, El Pueblo Gallego, Hierro, Sur and Odiel); and, on the other hand, the tabloid Pueblo, owned by the Vertical Trade Union until 1976. In April 1977, once the National Movement had been dissolved, all of them -except Pueblo, which did so in June 1978-, were added into the Social StateOwned Media (MCSE). They remained as part of this autonomous organism until their disappearance between 1979 and 1984, which had been decreed by governmental orders passed in June 1979 and January 1984, as mentioned above.

Whereas the selection of Pueblo does not need much more justification, since it was a differentiated unit within the official press (Naseiro Ramudo, 2013), why have we selected the six aforementioned tabloids among the 34 plausible ones? For their collection, we have followed the criteria of geographical edition (centralism versus regionalism and localism) and the grade of diffusion (national, regional or local running) proposed by Winner and Dominick (2000: 141-144). Therefore, these criteria have led us picking two national running newspapers edited in Madrid -the capital of Spain-, one regional, edited in Málaga (Andalucía) and four local ones, edited in Barcelona (Catalunya), Vigo (Galicia), Bilbao (Basque Country) and Huelva (Andalucía):

1‥ Central newspapers: National running tabloids edited in Madrid:

> Arriba: national-reference newspaper for the Movement press' chain. Running over 20,000 daily copies sold during the Spanish Transition, it was "the Dictator's voice", according to D'Amico (2008) 
Pueblo: Vertical Trade Union's evening newspaper. Reaching a diffusion of up to 179,000 copies sold on a daily basis, it counted on 650 journalists in staff during our studying period.

20. Newspapers edited in territories with a long nationalist tradition:

$>$ Solidaridad Nacional, Barcelona (Catalonia): it was the reformulation of a Communist tabloid confiscated during the Spanish Civil War, which had been owned by the CNT (Workers National Confederacy) during the Second Republic, Solidaridad Obrera. It had a circulation of 5,400 daily copies sold in those years.

$>$ El Pueblo Gallego, Vigo (Galicia): having been engendered with a clear regionalist aim in 1924, and held as Francoist propaganda tool during the dictatorship, it sold 5,100 daily copies during the transition.

$>$ Hierro, Bilbao (Basque Country): Evening newspaper that occupied the facilities of the socialist tabloid El Liberal which, after having been seized in 1937 by the Francoist troops and put at the disposal of the Francoism, run 5,200 daily copies between 1975 and 1978.

3‥ Newspapers edited in a territory with a long regionalist tradition: dailies published in Andalucia, the fourth Spanish community that gained the autonomy. It did so in 1981 (Fusi, 1996).

$>$ Sur, Malaga: regional-reference newspaper for the chain of the Movement's press in Andalucia, and the only one economically profitable, acccording to Ruiz Romero (1998). It had a circulation of 22,659 daily copies during the transition to democracy.

$>$ Odiel, Huelva: founded by the PRC (Republican-Conservative Party) in 1935 , it had the lowest difussion in Andalucia during this period $(5,755$ daily copies sold).

Therefore, we have focused on seven official newspapers edited in five communities of the country: Madrid, Catalonia, Galicia, Basque Country and Andalucia. This is, the Spanish capital and the four first territories that gained the autonomy. Once selected the newspapers, we proceed to apply the biographical and technical study proposed by Casasús (1985) to them.

\subsection{Methodological tools}

To carry out this phase of the research we have set up a biographical and technical analysis card (reworked over Mauri's proposal, 2010, which also was a revision of that proposed by Casasús, 1985), which has permitted us to get to know the chosen dailies, 
the sections they created during the Transition, etc. This study has enabled us to learn up to what extent the studied newspapers evolved structurally and journalistically during our analysing period, as assumed by our first hypothesis. It has also allowed us to identify the ideology of the writers who worked with the selected tabloids during the political change. Thus, this latter learning has entitled us to validate or refute our second hypothesis, which assumed that different ideologies got into the official press during the Spanish Transition as a reflection of the controversial political and social landscape existing in the country at the time.

The following chart shows the biographical analysis card applied to each of the picked tabloids:

Chart 1: Biographical and technical analysis card

\begin{tabular}{|c|c|c|c|}
\hline \multicolumn{4}{|c|}{ REGISTER AND ADMINISTRATIVE DATA } \\
\hline \multicolumn{4}{|c|}{ Newspaper's name } \\
\hline \multicolumn{4}{|c|}{$\begin{array}{l}\text { Subtitle, motto and other elements in the } \\
\text { newspaper }\end{array}$} \\
\hline \multicolumn{4}{|c|}{ Place of edition (city, province, community) } \\
\hline \multirow{2}{*}{\multicolumn{2}{|c|}{ Days and hours of distribution }} & Morning & \\
\hline & & Afternoon & \\
\hline \multirow{5}{*}{\multicolumn{2}{|c|}{ Official languages used }} & Spanish & \\
\hline & & Catalan & \\
\hline & & Galician & \\
\hline & & Basque & \\
\hline & & Other $^{2}$ & \\
\hline \multicolumn{4}{|l|}{ First edition } \\
\hline \multicolumn{4}{|l|}{ Last edition } \\
\hline \multicolumn{4}{|c|}{ Diffusion or circulation } \\
\hline \multicolumn{4}{|c|}{ Price } \\
\hline \multirow{2}{*}{\multicolumn{2}{|c|}{ Price of subscription }} & Month & \\
\hline & & Year & \\
\hline \multicolumn{4}{|c|}{ Extraordinary editions } \\
\hline \multicolumn{4}{|c|}{ Incidents, suspensions, fines, etc. } \\
\hline \multicolumn{4}{|c|}{ Collections preserved } \\
\hline \multicolumn{4}{|c|}{$\begin{array}{l}\text { Archives, libraries and digital newspaper archives } \\
\text { whereby you can access to the original source }\end{array}$} \\
\hline \multicolumn{4}{|c|}{ External references in press } \\
\hline \multicolumn{4}{|c|}{ Editions preserved } \\
\hline \multicolumn{4}{|c|}{ Newsroom's address } \\
\hline \multicolumn{4}{|c|}{ Administration's address } \\
\hline \multicolumn{4}{|c|}{ Printer's address } \\
\hline \multicolumn{4}{|c|}{ FORMAL AND CONTENT DATA } \\
\hline \multirow{2}{*}{\multicolumn{2}{|c|}{ Format and presentation }} & Tabloid & \\
\hline & & Broadsheet & \\
\hline \multicolumn{4}{|c|}{ Measures: base per height } \\
\hline \multirow{2}{*}{$\begin{array}{l}\text { Printer } \\
\text { techniques }\end{array}$} & Typography & & \\
\hline & Colour & Black and white & \\
\hline
\end{tabular}

\footnotetext{
${ }^{2}$ We have not included 'Andalusian' as a language option as it is not an official language in Spain, but a dialect.
} 


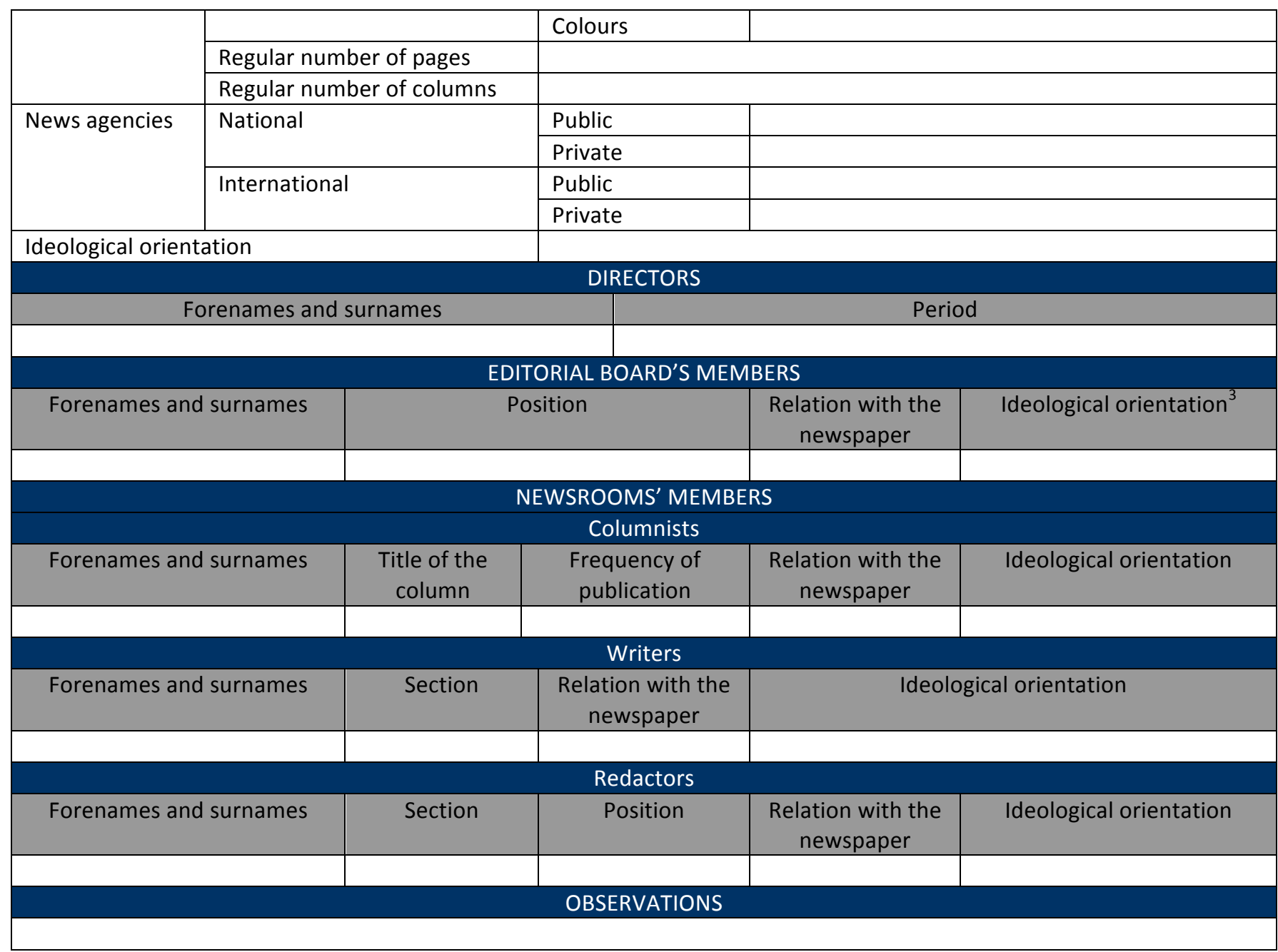

\section{Source: Own elaboration}

Once we have applied the biographical analysis card to the picked newspapers, it is time for interpreting the data resulting. To carry out this phase of the study, we have firstly focused on the editorial board's and the newsrooms' renewal and the creation of new sections in the selected newspapers, especially concentrating in those discussing over national politics and public affairs issues. This stage has allowed us to validate our first hypothesis. Secondly, we have identified the ideological orientation of each of the journalists working with the official press during our studying period, which, as said above, has enabled us to validate our second hypothesis.

Therefore, this study has entitled us to demonstrate whether the official press evolved structurally, ideologically and journalistically during the transition to democracy, or remained as it was engendered during the dictatorship, not allowing the entry of any other ideology.

\footnotetext{
${ }^{3}$ We have pointed out the writers' ideological orientation when we have found official records in which they are registered as militants of any of the political parties existing at the time, or when they identified themselves as supporters of one ideology or another in the texts they signed.
} 
All this said we now proceed to present the findings resulting from this research.

\section{Results and discussion}

\subsection{Structural evolution of the official press during the transition ${ }^{4}$}

The editorial board and the staff of the official press faced a deep renewal between Franco's death and the referendum on the Constitution, as shown in the following chart:

Chart 2: Staff's renewal in the official press (1975-1978)

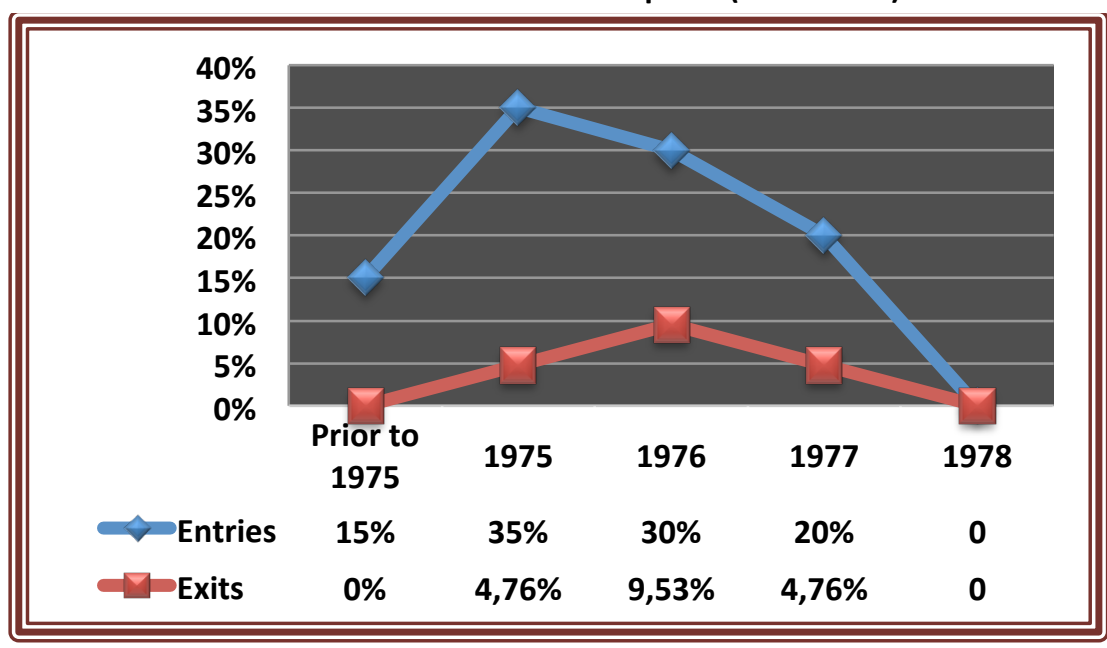

Source: Own elaboration.

The previous chart reveals that the $35 \%$ of the members working with the official press started its relation with the chain when Franco died, thus coinciding with the convulsion occurred within a regime which faced the uncertainty of going on existing as an authoritarian state without authority at all, as Franco represented the charismatic authority (Zugasti, 2005). The $30 \%$ did so in 1976, coinciding with Arias Navarro's resignation and Adolfo Suarez's inauguration as President of the Government, which may be interpreted as a support to the new Head of the Government. In 1977, with the dissolution of the National Movement by the law $1 / 1977$ of $1^{\text {st }}$ of April, the remaining

\footnotetext{
${ }^{4}$ In this first chapter, we will explain the results concerning to the newspapers Arriba, Solidaridad Nacional, El Pueblo Gallego, Hierro, Sur and Odiel.
} 
$20 \%$ of the workers got into the daily. Considering that this political action entailed the end of the Francoism ruling the official press, these incorporations might be understood as a reaction to a new era within the official press. Likewise, this in/out flow constitutes itself a renewal of up to $85 \%$ of the staff that worked with the official press during the Spanish Transition.

Most of them $(80,96 \%)$ kept on working with the chain, firstly with the movement's press and afterwards with the MCSE, even after 1978, moment in which our study ends. Concerning the out flow, the $4,76 \%$ of the workers left the chain in 1975, after Franco died, and the same number did it in 1977, once the National Movement was dissolved, which may be interpreted as a rejection on the part of the journalists to go on working with a press that did not count with the ideological support of the Movement. In this connection, we have noticed that most of them emigrated to rightist trend newspapers and journals, such as El Alcázar-. The remaining 9,52\% did so after Arias' resignation and the appointment of Suarez as president (July 1976). This last exit flow from the newspaper could be also understood as a rejection to the new Head of the Government, who represented the approach to democracy.

Thus, we have noticed that in moments of political convulsion when the authoritarian institutions were dissolved, some writers abandoned the official newspapers, and others came in. This fact also proves that, whenever the political transition went ahead approaching to democracy, the official press made ahead in the same line in its attempt to adapt itself to the new political landscape. This statement accounts for the fact that when Adolfo Suárez was appointed as President of the Government rightist trend journalists abandoned the official newspapers, and leftist trend ones came in. Therefore, as assumed by our first hypothesis, there was a deep evolution in the chain's structure, as had been pointed out as plausible by Castro Torres (2010).

Due to this in/ out staff flow in the official press, also, different ideologies got into its newsrooms, and into the editorial boards ${ }^{5}$. Thus, Fernando Ónega and José Cavero, centrism's supporters and pro- UCD, were deputy directors for the chain during the transition to democracy. They shared this responsibility with Falangists, such as Pedro Rodríguez and Mariano del Mazo Zugazagoitia, and socialists and unionists, such as Jose Antonio Gurriarán. This statement validates partially our second hypothesis, which assumed that part of the adaptation that the official press underwent was the inclusion of different ideologies within the newsrooms.

\footnotetext{
${ }^{5}$ The reader can see a complete list of the renewal in the editorial boards in the newspapers selected for this study (Arriba, Pueblo, Solidaridad Nacional, El Pueblo Gallego, Hierro, Sur and Odiel) in Appendixes of MARTÍNEZ FÁBREGAS, Jezabel (2014): La imagen del Gobierno en la prensa oficial durante la Transición española (1975-1978). Análisis comparativo de Arriba, Pueblo, Solidaridad Nacional, El Pueblo Gallego, Hierro, Sur y Odiel. PhD Thesis, Seville University (Spain).
} 
On the other hand, during the analysing period, only one of the official newspapers, the national-reference one, Arriba, changed its director. Cristóbal Páez resigned as Arriba's director in July 1976, and Alejandro Armesto filled his shoes until the closing down of the tabloid in 1979. The rest of the dailies kept their director during the studying period.

Contrariwise to the stability reigning in the direction of the studied papers, the editorialism faced deep alterations during the analysing period. Thus, when Franco died the editorials lacked of a regular frequency of publication: two texts per week. This fact changed considerably in July 1976, thus coinciding with the first change in the Government in charge of the management of the political transition, the moment in which Adolfo Suárez was inaugurated as president of the Executive. Henceforth, editorials increased their presence in the official tabloids, reaching the figure of up to three texts published per day. Not only did editorialism adjust its frequency of publication, but also its format. Thus, the extension of the editorials considerably increased, occupying up to a full page during the analysing period.

This happening shows a determination on the part of the state-owned press for giving account of the political process that was occurring in Spain, providing the readers with their interpretation on public affairs issues. Likewise, this also proves that the official press was committed to its role as a political agent, as assumed by our first hypothesis.

In the same way the editorialism registered changes, columnism and articulism also faced adjustments during our analysing period. Hence, on the one hand, we have observed that the columns on political issues considerably increased, up to $65 \%$, during the transition. This was the result of the creation of several fixed-columns (10) and temporary-columns (15) dealing with political issues. In this connection, "La política y los días", "El Péndulo", and "La vida cotidiana", among others, are examples of the fixed columns that focused on national politics and public affairs issues happening at that moment. Similarly, "Elecciones 15-J", "Actas del tiempo que llaman de la reforma" or " Temas para después de un referéndum", were short-term columns launched by the official press for the analysis of relevant political actions undertaken in concrete moments throughout the political transition. The creation of these new spaces for the political analysis of the transition provides evidence of the fact that the official press was opening its gates to different interpretations of national politics, thus setting itself up as an active political agent, as assumed by our first hypothesis.

In addition to these formal and content alterations, we have also checked the entry of different ideologies to the official press' columnism and articulism, such as CentrismUcedism, Socialism, Communism, among others, as shown in the following chart: 


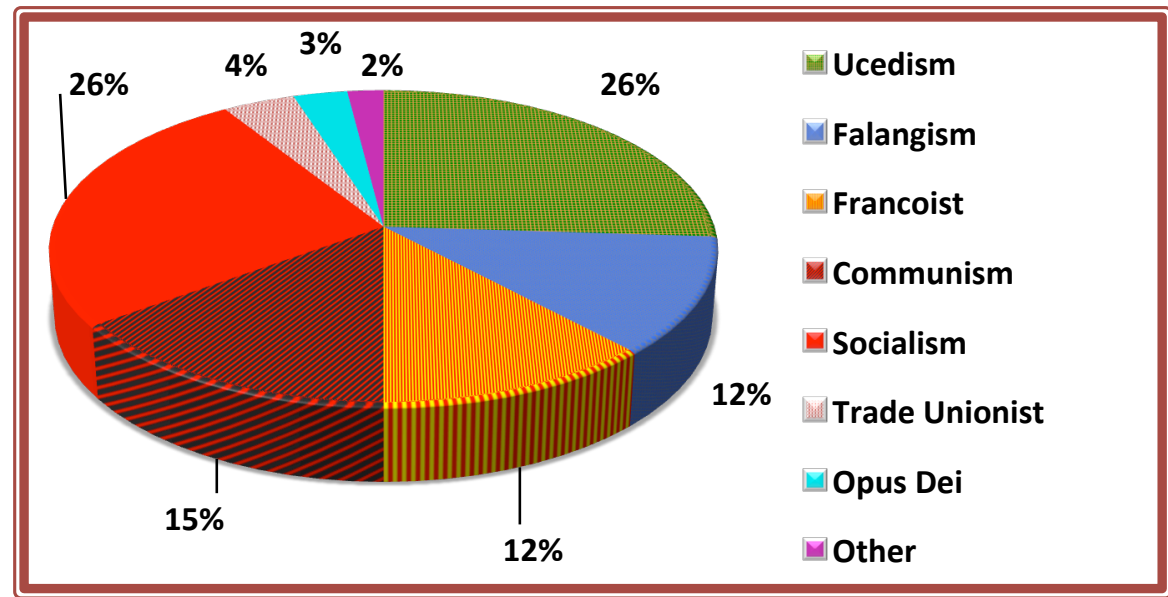

Chart 3: Ideologies present in the official press' columnism and articulism (1975-1978)

Source: Own elaboration

The former chart, joined to the qualitative data resulting from the biographical analysis applied to the selected newspapers, reveals that Falangists (Francisco Muro de Iscar and Jesús Suevos Fernández), priests (Esteban Graciet), centrists and ucedists (Carlos E. Rodríguez and Fernando Ónega), and Communists (César M. Arconada), among others, worked with the official press during the Spanish Transition. Likewise, the articulism also welcomed writers who professed different ideological orientations during this period. Thus, Francoists, as Salvador López de la Torre, Falangists, as José Antonio Cepeda González, centrists and ucedists, as José Cavero Jáñez and Fernando Lanzaco, Regionalists, as Carlos Arauz Robles (from the Galician Political Party), and members from the Opus Dei, as Ismael Crespo Herraiz, gathered in the official press during the Spanish Transition.

In this connection, the previous chart provides also evidence of the existence of ideological confluence within the Francoist press during the Spanish Transition, as assumed by our second hypothesis. This, joined to the creation of the new spaces for the dispute over political issues mentioned above, the structural changes occurred within the official press during the Spanish Transition, and the renewal in both the newsrooms and the editorial boards, are the evidences of the fact that the official press evolved and took on its role as political agent, as assumed by our first hypothesis. These findings, likewise, contradicts to Alférez (1986) and to Montabes Pereira (1989), who considered that the official press neither modified its structure during the transition to democracy nor welcomed different ideologies in its newsrooms.

Once the findings concerning to the official tabloids previously ascribed to the Movement's Press and subsequently added into the MCSE (April 1977) presented, we proceed now to explain the results concerning to the trade-unionist tabloid, Pueblo. 


\subsection{Structural evolution of Pueblo during the transition}

The syndicalist newspaper faced up to four alterations in its direction during the Spanish Transition. The falangist Emilio Romero ruled this tabloid until he was succeeded by Luis Ángel de la Viuda in January 1976. When the latter resigned to his position in March 1976, Juan Fernández Figueroa filled his shoes until July that year, moment in which José Ramón Alonso was appointed as the daily's director, being in charge of its management until December 1978. Hence, his arrival to Pueblo coincided with Arias' resignation and Suarez's inauguration as President of the Government. These constant adjustments provide evidence of the fact that, as soon as Franco died, the newspaper started to seek the orchestra conductor who guaranteed its survival within the competitive-journalistic market existing at the time.

Conversely to the frantic changes occurred in the daily's direction, the evolution process of the newspaper was quieter during the studying period. Thus, the $62,5 \%$ of the members working with the broadsheet already held a contractual relation with it before Franco died; the $25 \%$ got into the daily's newsroom after November 1975 , coinciding with the leader's death, the start of a new era without authority; the 8,33\% of them did so in 1976, when Arias Navarro reisgned and Suárez filled his shoes as the Head of the Government, and $4,16 \%$ in 1978 , when the referendum on the Constitution was held.

Concerning to the out-flow staff, $41,66 \%$ of the writers left the tabloid in 1979, coinciding with the moment in which the first official newspapers closed down in compliance with the governmental order that decreed so, the $20,33 \%$ did so in 1981 , and the $12,5 \%$ of them did so when the National Movement got dissolved in 1977, and when the referendum on the Constitution was held in 1978 , respectively. So, just the $25 \%$ of the staff abandoned the newspaper during the analysing period.

Therefore, Pueblo kept the $75 \%$ of the writers, who were in staff prior to Franco's death, until, at least, December 1978, coinciding with the referendum on the Constitution. Nevertheless, in spite of the stability, we must highlight the outstanding incorporations of writers $(37,49 \%)$ occurred between 1975-1976, period in which the convulsion due to the demise of Franco was stronger and the uncertainty about the continuity of the regimen brought about the adjustments in the direction of the tabloid. The in flow, although intense during this period, stopped almost completely in 1976, when Adolfo Suárez was inaugurated as the new Head of the Government. It was also then when the out flow from the newspaper started to increase unstoppably until the closing down of the broadsheet in 1984. This latter fact constitutes a renewal through which the newspaper tried to go away from Francoism in order to adapt itself to the new political and ideological landscape. The next chart shows the renewal of Pueblo's staff during the Spanish Transition: 
Chart 4: Staff's renewal in Pueblo (1975-1978)

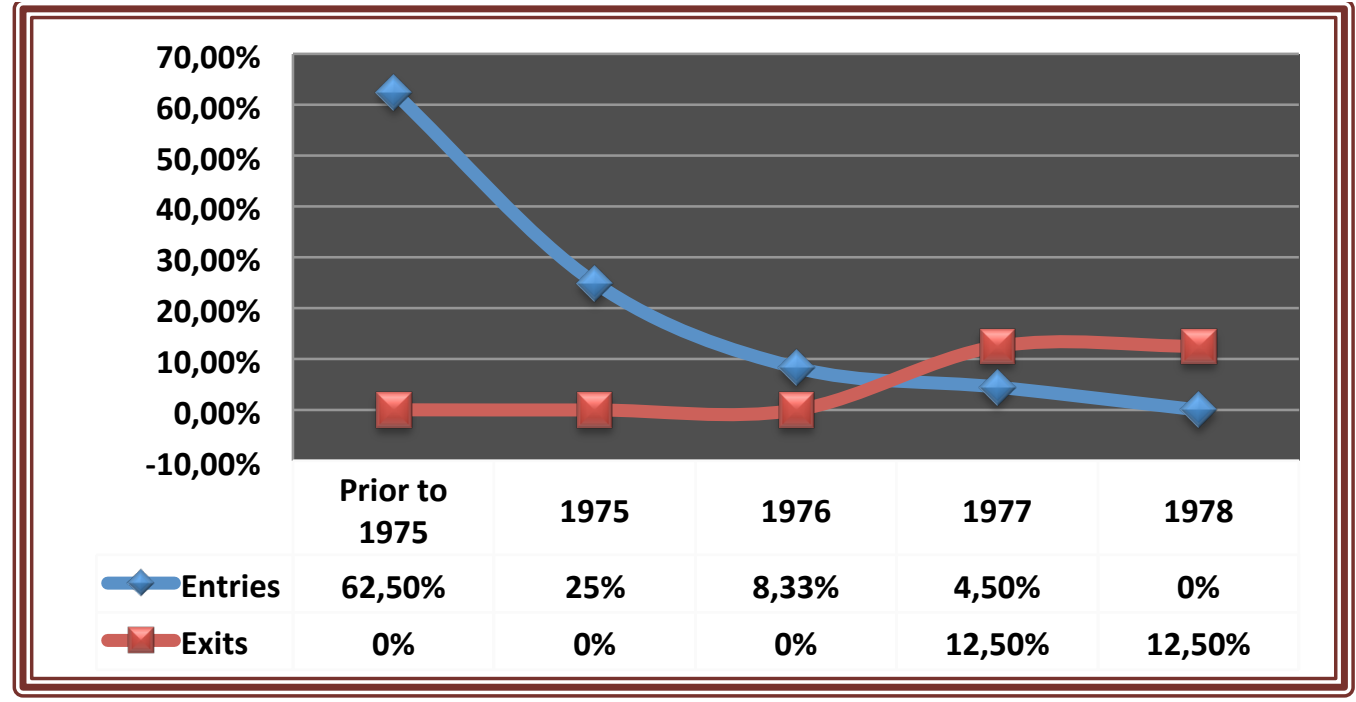

Source: Own elaboration

The in/ out staff flow occurred in the newspaper during our studyng period allowed that socialists (Homero Valencia, National section's chief between 1975 and 1978), syndicalists from UGT, General Workers Union, (José María Pérez de Castro, deputy director between 1975 and 1981), Centrist-Ucedists (Ángel Gómez Escorial, editor in chief between 1966 and 1980), Francoists (Germán López Arias, editor in chief from 1974 to 1979), priests (Antonio Aradillas, deputy director until 1979) and Communists (Javier Martínez Reverte, editor in chief between 1973 and 1978), coincided in the syndicalist newspaper's editorial board.

Likewise, these modifications within the syndicalist daily's editorial board, joined to the convulsion experienced in the daily's direction, also affected the editorialism during this period. Thus, whereas the publication of editorials was very irregular in terms of frequency at the beginning of the studying period, just two texts per week, up to three editorials per day were published from July 1976 onward, thus coinciding with the moment in which Adolfo Suárez was inaugurated as Head of the Government, which also matched with the incorporation of Juan Ramón Alonso as the director of Pueblo.

Additionally, editorials increased their interest in political issues up to a $64 \%$ compared with the previous phase (Francoism). In this connection, the fact that editorials gained regularity in terms of frequency of publication shows that this newspaper was trying to assume its role as a political agent within the Spanish journalistic market, by increasing its activity as a narrator and commentator of the political transition. Moreover, the editorials also gained extension, filling ocassionally up to a full page. And they also 
included illustrations with which the editorialists signed their texts. Some of the chosen were three stars $\left({ }^{\star \star \star}\right)$, a sun $\left({ }^{\prime \prime}\right)$, a spiral (@), or his own initials (JRA).

On the other hand, the staff's renewal came also along with adjustments in Pueblo's columnism and articulism. Thus, we have constated the creation of up to 12 fixed columns that dealt with political issues, such as "Lo político" or "Tribuna", for instance. In addition to this, the newspaper also published some occasional columns, specifically created for disputing over concrete political actions (referendum on the political reform, general elections, referendum on the Constitution, etc.), and commissioned to well reputated writers. Hence, columns such as "Punto de mira", "La Hora del mundo" or "Análisis político", were published occasionally in the ninth page, the one that the syndicalist broadsheet reserved for the external opinion during the analysing period. Accordingly, the number of columns dealing with political issues and public affairs published in the newspaper during the transition increased up to a $45 \%$, which is an evidence of the newspaper's determination for taking on its role as a political agent, as assumed by our first hypothesis.

The aforementioned adjustments also affected to the content published in articles and columns. This modification finds its rationale in the fact that the external writers were allowed to freely express their point of view on political issues in the newspaper's opinion pages. How did they get this permission? By including the heading "Texts included in this page express their author's opinion. Pueblo's editorial line is not responsible for the opinions disseminated by signed articles", the daily got exempted from legal responsibility resulting from the writers' opinions. Thus, journalists were free to express their opinion being legally responsible for them before the law.

The fact that the newspaper included the aforementioned heading in order to avoid legal responsibility for the texts published in it provides evidence of the fact that the editorial board was totally aware of the controversy existing in the external opinion page due to the ideological pluralism existing in Pueblo's articulism and columnism, as shown in chart 5 :

Chart 5: Ideologies present in Pueblo's columnism and articulism (1975-1978) 


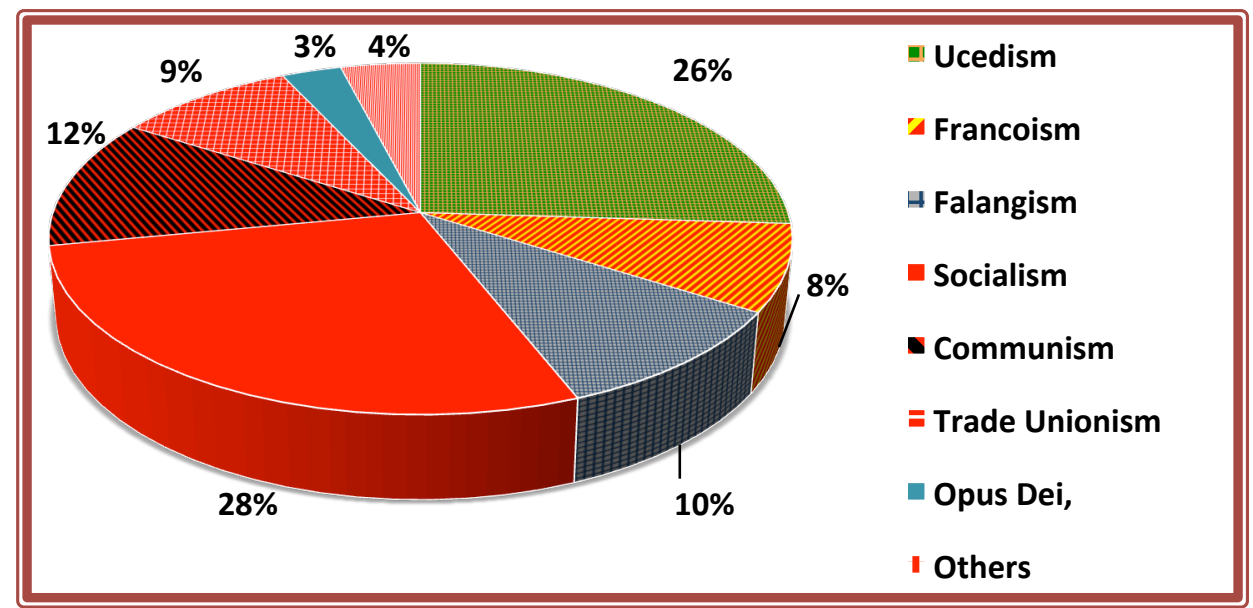

Source: Own elaboration

The data here presented, joined to the qualitative data resulting from the biographical analysis applied to Pueblo, reveal that there was an outstanding ideological diversity within its columnism and articulism during the studying period. This heterogeneity ranged from Ucedism (Pilar Narvión and José Cavero Jañez) to Socialism (Manuel Cruz), passing by Falangism (Jaime Campmany y Díez de Revenga), Francoism (Carlos Iglesias Selgas), Anarcho-syndicalism (José Elizalde), and Communism (Jesús del Pozo), among others ${ }^{6}$. The confluence of such an ideological pluralism within this newspaper was reason enough for introducing the exonerating heading quoted above, since we have to bear in mind that Spain was yet an authoritarian regime (Guillamet, 2002).

Once this explained, we can asseverate that these structural and ideological updates occurred in Pueblo during the Spanish Transition allowed the syndicalist tabloid to welcome different ideologies both in its editorial board, as well as in its columnism and articulism, as assumed by our second hypothesis. Moreover, these frantic modifications happened in the tabloid contributed to it took on its role as a narrator and commentator of the democratising process that Spain was undergoing at that moment. This is, assuming its role as a political agent.

Once the evolution of Pueblo explained, we proceed now to explain the ideological progression of the studied newspapers during the studying period.

\subsection{Ideological evolution of the official press}

When Franco died in 1975, he had left "everything tied and well tied" (English translation of Franco's famous sentence: "Todo está atado y bien atado"). Thus,

\footnotetext{
${ }^{6}$ The reader can find a report of any journalist's ideology orientation pointed out in this paper in the Doctoral Thesis MARTÍNEZ FÁBREGAS, J. (2014): La imagen del Gobierno en la prensa oficial durante la Transición española (1975-1978). Análisis comparativo de Arriba, Pueblo, Solidaridad Nacional, El Pueblo Gallego, Hierro Sur y Odiel, Universidad de Sevilla España.
} 
freedom of expression was not expected in the official press. In spite of the fact that the Francoism's detractors had been working with the official press even during the dictatorship (Peña Marín, 1980), Emilio Romero (1992) stated that the official press' rulers had handled that situation by making the workers "swallowed their opinions against the regime". This is why, historians, such as Montabes Pereira (1989) and Alférez (1986), highlight that official press went on being a propaganda tool under an authoritarian regime during the Transition.

In this connection, once we have analysed the ideological evolution of the official press, including Pueblo, we can assert that, in November 1975, only Falangism, Francoism, Catholicism and Opus Dei had access to the official press' pages. This did not mean the absence of other ideologies within it, although they never reached the opinion pages.

Nevertheless, this landscape changed considerably during the studying period because of two facts occurred in the political arena. On the one hand, the dissolution of the National Movement and the Vertical Trade-Union forced the Francoist press to evolve structurally, in order to survive within the in-boom journalistic market existing at the time, as we explained above. On the other hand, the ideological pluralism existing in the country was reflected into the official press, by allowing the entry of different ideologies within it, as we have already explained in the previous chapter.

These facts prove that, during our analysing period, the official press broke the immobilised structure it had had until then. The following charts (6 and 7) show the ideological diversity present in the official press in the beginning and the end of our studying period. This is, 1975 and 1978. The data presented here has allowed us to know up to what extent the official press, all the analysed newspapers studied, evolved ideologically during our studying period:

Chart 6: Ideologies within the official press in 1975

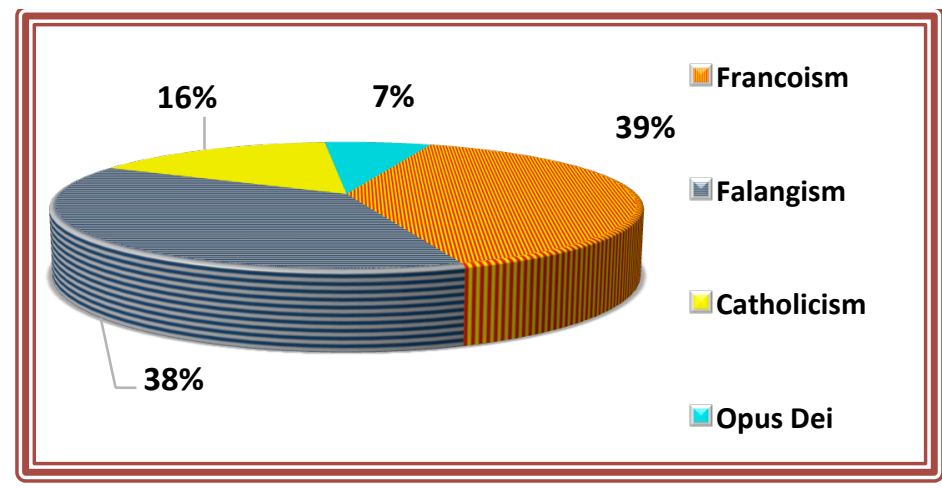

Source: Own elaboration.
Chart 7: Ideologies within the official press in 1978

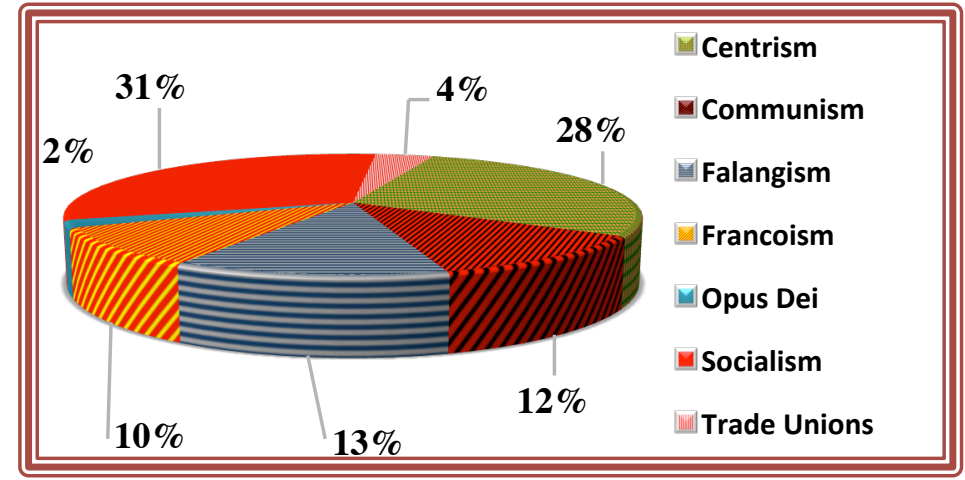

Source: Own elaboration. 
The charts reveal that during the Spanish Transition, there was an ideological evolution within the official press, which was the reflection of the political pluralism reigning in the country at the time. Hence, whereas Francoism and Falangism were the most represented currents of thought in the official press until Franco's death in 1975, at the end of the studying period, a total inversion had occurred. The Socialism and the Ucedism had substituted the Francoism and the Falangism as the most represented ideologies within the state-owned press. Relegated to the background Francoism, Falangism and Communism, and in a very discreet position, the Trade Unions and Opus Dei were.

This fact shows that, contrariwise to what Alférez (1986) and Montabes Pereira (1989) had traditionally asserted, the official press considerably evolved during the Spanish Transition. Not only in structural terms but also at ideological and journalistic levels, as assumed by our hypotheses, and pointed out as plausible by Castro Torres (2010) and Meneses (2008). It also proves that, in its desperate attempt for adapting itself to the new political landscape in which it did not count on the financial and the political support provided by the Francoist institutions, the official press opted for opening its gates to different ideological currents.

Likewise, this study has proved that columnists and articulists counted on all the required tools and the support of the official press to become into the guarantors of the opinion pluralism of the newspaper they were working with, thus taking on their role as political agents (Borrat, 1989), as assumed by our second hypothesis.

Once the results exposed and the discussion presented, we proceed to present the conclusions we have arrived to in this paper.

\section{Conclusions}

The official press evolved structurally, ideologically, and journalistically during the Spanish Transition. On the one hand, this was the result of the lost of the financial and political support that the National Movement and the Vertical Trade Union had provided it during the Francoist Dictatorship. However, once these institutions had been dissolved, the state press was left to its fate and it had to adapt itself to the new political, ideological and journalistic landscape.

To face this evolution process $t$, during the first 9 months of the analysing period (from November 1975 to July 1976), the Francoist press was convulsing the same way the political system did, because of Franco's demise. However, calm arrived to the official press when Adolfo Suarez became President of the Spanish Government, in July 1976. From then onward, we have observed a determination on the part of the state-owned 
press for assuming its role as a political agent. By carrying out two actions, this determination materialised.

On the one hand, the staff renewal, both in the editorial boards as well as in the columnism and the articulism, came along with the reinvention of the official press. Part of this reform was the inclusion of several columns, both fixed as well as occasional, that dealt with political issues, and which constituted a journalistic renewal itself. Additionally, they created spaces reserved for the 'external opinion', in which the writers could freely express their own point of view, independently of the editorial's dictates. This fact shows an increase in the determination on the part of the official press for turning itself into an open space reserved for opinion pluralism.

On the other hand, different ideologies got into the official press during the transition thanks to the staff's renewal mentioned above. This fact proves that the state press also evolved ideologically, embracing different ways of interpreting the democratising process that Spain underwent during the transition to democracy.

To conclude, the state-owned press progressively abandoned the propaganda structure with which it had been engendered, by renewing its staff, opening its gates to ideological pluralism, and reinventing itself at a journalistic level, thus setting itself up as a political agent.

\section{Bibliography}

ALFÉREZ, A (1986): Cuarto poder en España: La prensa desde la ley Fraga de 1966. Madrid: Plaza \& Janés.

ALMUIÑA FERNÁNDEZ, Celso (1991): Fondos y metodología para el análisis de prensa local a AA.VV. Fuentes y métodos de la historia local. Instituto de Estudios Zamoranos "Florián de Ocampo". Zamora: Diputación de Zamora, Confederación Española de Centro de Estudios Locales.

ANGUERA, Pere, GAVALADA, Antoni y PUJADAS, Xavier (1996): La prensa a la provincia de Tarragona durant la segona república 1931-1936. Tarragona: Diputació de Tarragona.

BARRERA, Carlos (1995): Sin mordaza. Madrid: Temas de hoy.

BERELSON, Bernard (1952). Content Analysis. In: Handbook of Social Psychology, Vol I. Nueva-York.

BORRAT, Héctor (1989) El periódico actor político. Barcelona: Gustavo Gili. 
CASASÚS, Josep María (1985): Ideología y análisis de medios de comunicación. Barcelona: Mitre.

CASTRO TORRES, C. (2010). La Prensa en la transición española 1966/1982. Madrid: Alianza Ensayo.

FUSI, J. P. (1996). "El desarrollo autonómico". En TUSELL, J.; SOTO, Á. Historia de Transición, 1975-1986. Madrid: Alianza Universidad.

GALLEGOS, S. L. (2003). "Aproximación al estudio de las publicaciones sindicales españolas desarrolladas durante el franquismo (1936-1975)". In Historia y comunicación social, (8), 159-185.

GARCÍA GALINDO, Juan Antonio; GUTIÉRREZ, Juan Francisco; SÁNCHEZ ALARCÓN, María Inmaculada (coords.) (2002): La comunicación social durante el franquismo. Málaga: Diputación Provincial de Málaga.

GUILLAMET, J. (2002): "Factores de progreso y atraso en la evolución histórica del periodismo. El franquismo". En GARCÍA GALINDO, J. A.; GUTIÉRREZ LOZANO, J.; SÁNCHEZ ALARCÓN, I. (eds.). La comunicación social durante el franquismo. Málaga: Centro de Ediciones de la Diputación Provincial de Málaga.

GUILLAMET LLOVERAS, Jaume (2003): “El periodismo en la transición del franquismo a la democracia: factores políticos, económicos y profesionales" en Aportacions de la comunicació a la comprensió i construcció de la història del segle XX; La comunicació audiovisual en la història / coord. por Sebastià Serra Busquets, Arnau Company Mates, Jordi Pons Bosch, Vol. 1.

LÓPEZ HIDALGO, A. (2012). La columna: periodismo y literatura en un género plural. Zamora: Comunicación Social.

LÓPEZ DE ZUAZO ALGAR, Antonio (1981): Catálogo de Periodistas españoles del siglo XX. Madrid: Facultad de Ciencias de la Información.

MARTÍN VIVALDI, G. (1987). Géneros periodísticos. Madrid: Paraninfo.

MARTÍNEZ FÁBREGAS, J. (2014): La imagen del Gobierno en la prensa oficial durante la Transición española (1975-1978). Análisis comparativo de Arriba, Pueblo, Solidaridad Nacional, El Pueblo Gallego, Hierro, Sur y Odiel. PhD Thesis, University of Seville (Spain).

MARTÍNEZ FÁBREGAS, J. (2015): "Propaganda and counter-propaganda in the official press during the Spanish Transition (1975-1978). Arriba vs. Odiel", in Ámbitos, Revista Internacional de Comunicación, num. 28. 
MARTÍNEZ FÁBREGAS, J. (2015): "El comportamiento de la prensa oficial con respecto al Gobierno Suárez durante las elecciones legislativas de junio de 1977". In Estudios sobre el mensaje periodístico vol. 21, № 1

MARTÍNEZ FÁBREGAS, J. y ROMERO DOMÍNGUEZ, L.R. (2014): “Arriba durante la Transición española: el abandono de su función propagandística con respecto al Gobierno", In Historia y Comunicación Social, núm. 19, 321-340.

MAURI DE LOS RÍOS, Marcel (2010): Funció i evolució de la prensa de Barcelona durant la transició democrática (1975-1978). PhD Thesis, Universitat Pompeu Fabra (Barcelona, Spain).

MENESES, D. (2008). Noticias sobre la prensa: imagen propia en la transición democrática. Madrid: Fragua.

MONTABES PEREIRA, J. (1989). La prensa del estado durante la transición política española. Madrid: Siglo XXI de España de Editores.

NASEIRO RAMUDO, Ana (2013): "El archivo del diario "Pueblo". Un referente para la historia de la prensa en España durante el franquismo y la transición democrática" en Documentación de las Ciencias de la Información, vol. 36, 11-29

PINEDA CACHERO, A. (2001). "El modelo de propaganda de Noam Chomsky: medios mainstream y control del pensamiento". En ÁMBITOS, no 6, Sevilla: Universidad de Sevilla, p. 191-210.

PINEDA CACHERO, A. (2006). Elementos para una teoría comunicacional de la propaganda. Sevilla: Ediciones Alfar.

POSTOUTENKO, K. J. (2010). Soviet culture: codes and messages. Bielfeld:Verlag Otto Sagner.

SÁNCHEZ, Glicerio (2002): "El sindicato vertical como instrumento político y económico del régimen franquista" en Pasado y Memoria, Revista de historia Contemporánea. №1: Instituciones y sociedad en el franquismo. Disponible en el siguiente enlace: www.publicaciones.ua.es/filespubli.pdf/15793311RD12141118.pdf

SOTO, Á. (1998). La transición a la democracia. Madrid: Alianza Editorial.

WINNER, R. Y DOMINICK J. (2000): Introducción a la investigación de medios masivos de comunicación. Ed. Thomson Editores.

WINNER Roger D. y DOMINICK Joseph R. (2000): La investigación científica de los medios de comunicación. Una introducción a sus métodos. Barcelona: Bosch Comunicación. 
VILLALOBOS SALAS, C. (2010): "El articulismo de opinión como fuente para la investigación histórica: el ejemplo del franquismo". En Espéculo: Revista de Estudios Literarios, no 47, p. 29.

ZALBIDEA, Begoña (1996): La prensa del movimiento: 1936-1983. PhD Thesis, University of Basque Country (Spain).

ZUGASTI, R. (2005): "La legitimidad franquista de la Monarquía de Juan Carlos I: un ejercicio de amnesia periodística durante la transición española" en: Comunicación y Sociedad, vol. XVIII, n. 2, pp.141-168. Disponible en el siguiente enlace: http://www.unav.es/fcom/comunicacionysociedad/es/articulo.php?art_id=87 